\title{
SIMULACE ZÁSAHU SLOŽEK INTEGROVANÉHO ZÁCHRANNÉHO SYSTÉMU PŘI REÁLNÉ DOPRAVNÍ NEHODĚ
}

\section{SIMULATION OF THE INTEGRATED RESCUE SYSTEM UNITS INTERVENTION DURING THE REAL TRAFFIC ACCIDENT}

Petr Veselík1, ${ }^{1}$, Kateřina Víchová ${ }^{2}$

\begin{abstract}
Abstrakt
Článek je věnovaný problematice záchranných a likvidačních prací složek integrovaného záchranného systému při reálné dopravní nehodě bez př́tomnosti nebezpečných látek. $V$ dnešní době se stále častěji setkáváme s mimorádnými událostmi různého charakteru, kdy významnou část zahrnují právě dopravní nehody. Teoretické i praktické poznatky ukazují, že zajištění požadované úrovně spolupráce záchranných složek může přispět ke snižení ztrát na lidských životech a snižení poškození zdraví účastníků zasažených mimořádnou událostí. Cílem článku je simulace společného zásahu složek integrovaného záchranného systému při reálné dopravní nehodě. K dosažení uvedeného cíle je použita sítová analýza, konkrétně metoda kritické cesty, která představuje sled vzájemně závislých činností s nejmenší časovou rezervou. Získané výsledky demonstrují jednu z možných variant optimalizace zkoumané činnosti složek integrovaného záchranného systému při řešení dopravní nehody.
\end{abstract}

Klíčová slova dopravní nehoda, integrovaný záchranný systém, Ganttův diagram, kritická cesta, krizové ř́zení, simulace, záchranné a likvidační práce

Summary The article is applied to the rescue and liquidation work of the integrated rescue system units during the real traffic accident without hazardous substances. Today, we are frequently encountering emergencies of different kinds, with a significant part of which include traffic accidents. Theoretical and practical knowledge shows that ensuring the required level of cooperation of rescue services can contribute to reducing the loss of human lives and reducing the damage to the health of participants affected by an emergency. The aim of the article is to simulate the intervention of the units integrated rescue system during the real traffic accident. Network analysis is used to achieve the paper's aim, specifically, the critical path method, a sequence of interdependent activities with the least time reserve. The obtained results demonstrate one of the possible variants of optimizing the investigated activity of the integrated rescue system units in solving the traffic accident.

Keywords Traffic Accident, Integrated Rescue System, Gantt Chart, Critical Path, Emergency Management, Simulation, Rescue and Liquidation Work

\footnotetext{
${ }^{1}$ Univerzita Tomáše Bati ve Zlíně, Fakulta logistiky a krizového řízení, Ústav krizového řízení, Studentské náměstí 1532, 68601 Uherské Hradiště, Česká republika

2 Univerzita Tomáše Bati ve Zlíně, Fakulta logistiky a krizového řízení, Ústav logistiky, Studentské náměstí 1532, 68601 Uherské Hradiště, Česká republika

*korespondenční autor, tel.: +420 576032 084, e-mail: veselik@utb.cz
} 


\section{1 ÚVOD}

V současné době jsme vystaveni velkému počtu hrozeb a z nich plynoucích rizik. Kampova et al. (2020) upozorňuje, že tyto hrozby jsou vysoce nepředvídatelné se širokou škálou následků. Snahou by mělo být tato rizika minimalizovat, aby se nemohla projevit nebo dostat na co nejnižší úroveň jejich škodlivé působení. $\mathrm{V}$ případě, že dojde $\mathrm{k}$ výskytu rizika, pravděpodobně se vyskytnou i mimořádné události (dále jen MU), s ním spojená. V současné době jsou MU na denním pořádku, a to jak ty způsobené činností člověka, tak i ty přírodní (Rehak et al., 2018). Autoři vědeckých článků (Batima et al., 2013), (Luskova and Leitner, 2018), (Munasinghe and Matsui, 2019) potvrzují rostoucí trend výskytu MU na celém světě. Postupem času bylo zjištěno, že některé MU mají potenciál pro významné zvyšování negativních důsledků (synergický efekt), zatímco jiné mohou mít za následek kaskádové poruchy (dominový efekt) (Bernatik et al., 2013).

Silniční doprava má v současné době v evropské dopravní síti nezastupitelnou roli. Tuto skutečnost podporuje výrazně vyšší rychlost motorizace a růst hustoty dálniční sítě v letech 2006-2016, ke kterému došlo prakticky ve všech evropských zemích (Rehak et al., 2020). Díky těmto faktorům dochází k vyššímu počtu MU v rámci silniční dopravy. Dopravní nehody představují vážné nebezpečí pro moderní společnost, protože mají za následek zranění, zdravotní postižení nebo dokonce ztráty na životech, spolu s významnými ekonomickými a sociálními důsledky.

Z obr. 1 je patrné, že technické havárie byly v roce 2019 nejčastější MU, při kterých zasahovaly jednotky požární ochrany (dále jen JPO), s počtem výskytů více než 72 tisíc, což představuje $56 \%$ z celkového počtu zásahů JPO. Dále ze statistik vyplývá, že druhou nejčastější MU, při které zasahovaly JPO byly dopravní nehody s počtem výskytů 22 tisíc, což odpovídá 17 \% z celkového počtu zásahů za rok 2019.

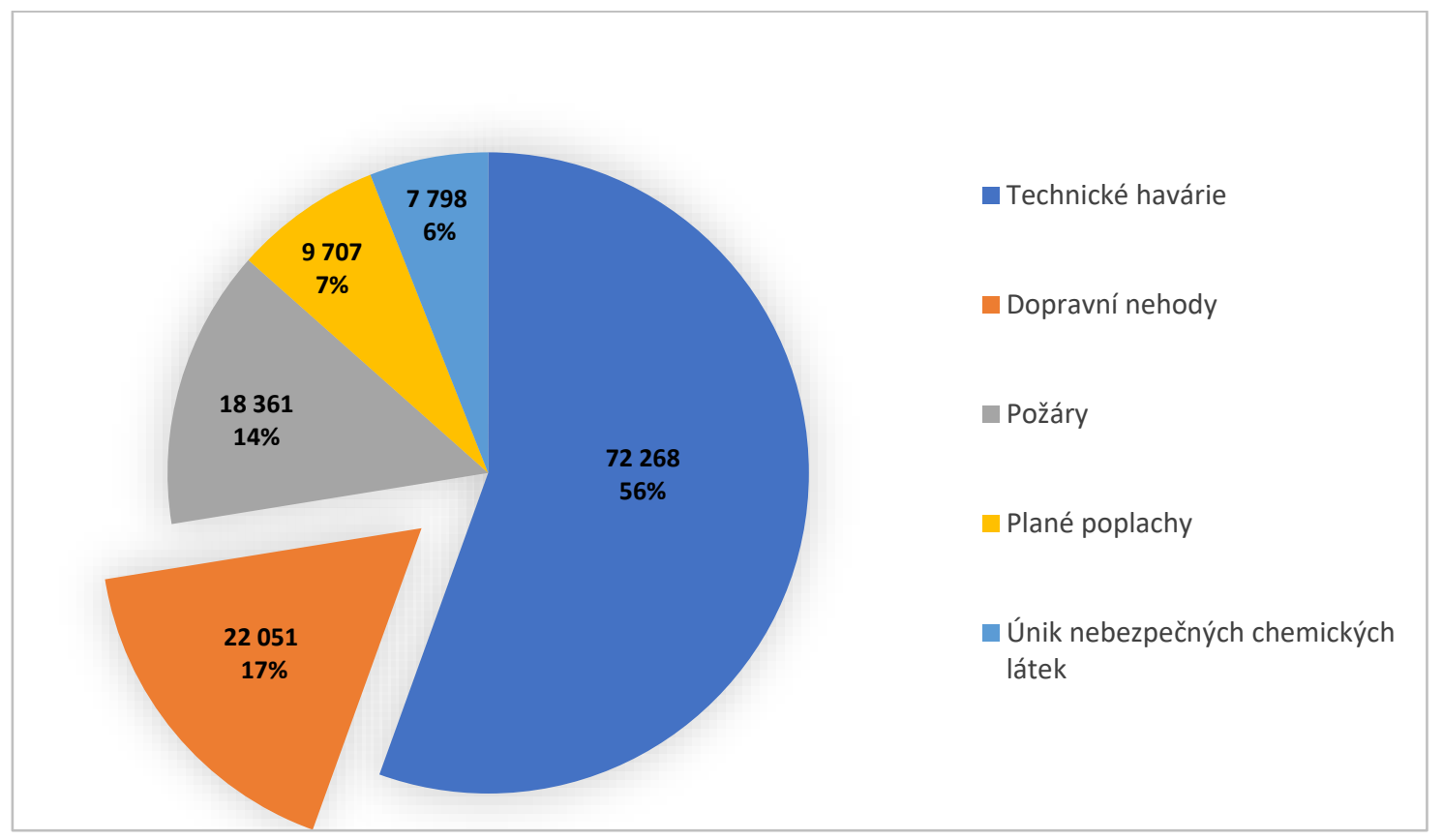

Obr. 1 Zásahy JPO v roce 2019 - počet a druh MU; zdroj: vlastní zpracování dle Nedělníková (2020) 
Následně byla zkoumána oblast spolupráce JPO s ostatními složkami v roce 2019. Obr. 2 níže zobrazuje spolupráci JPO s ostatními složkami, ze kterého je patrné, že v 60 \% př́ípadů spolupracovaly JPO s Policií ČR. Dále pak ve $26 \%$ př́́padů spolupracovaly JPO se zdravotnickou záchrannou službou (dále jen ZZS). Ze statistik je zřejmá i spolupráce s obecní policí, která činila $6 \%$. V neposlední řadě spolupracovaly JPO $\mathrm{s}$ pohotovostními a jinými místními službami, se správou a údržbou pozemních komunikací a podniky.

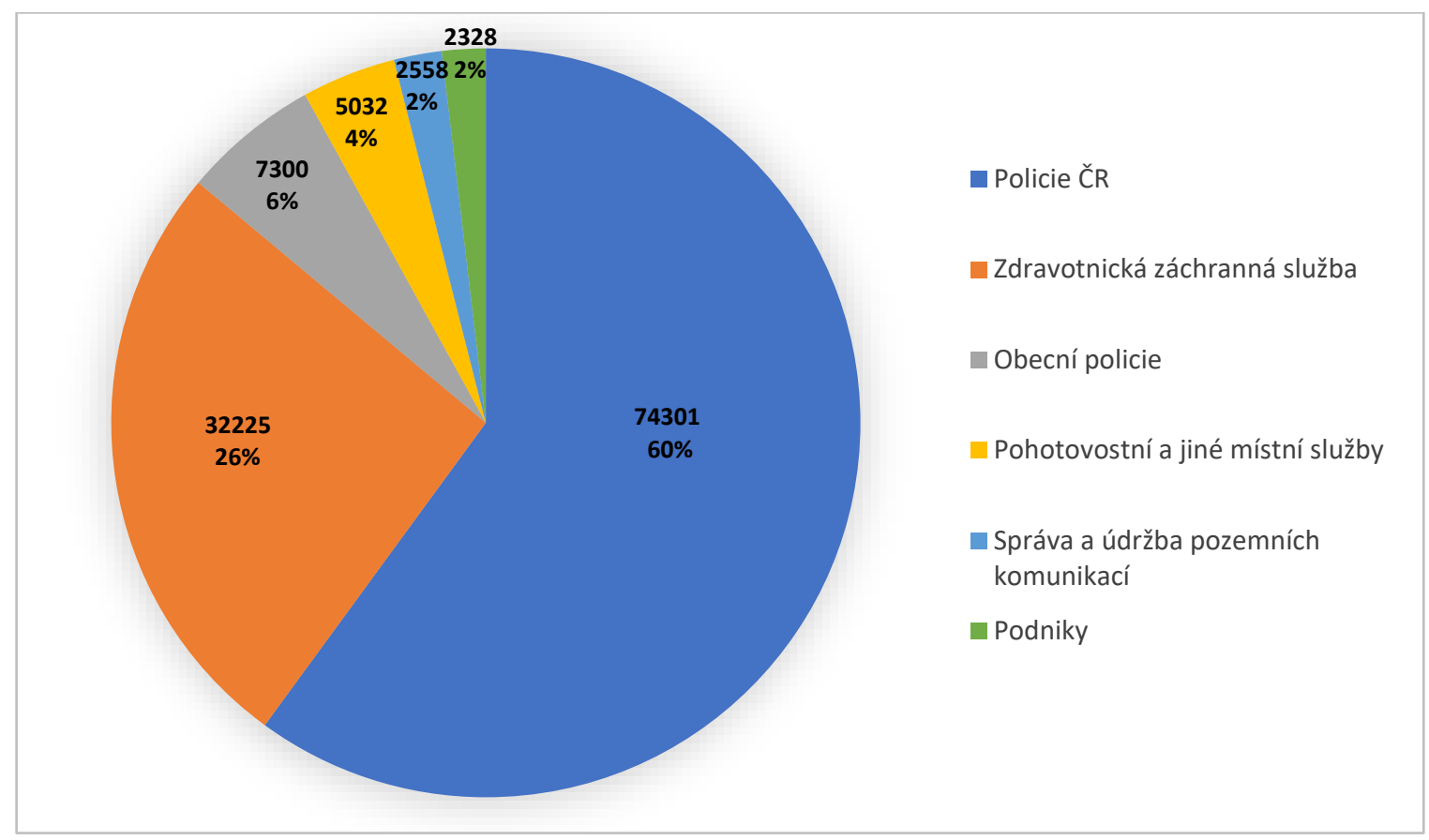

Obr. 2 Spolupráce JPO s ostatními složkami v roce 2019; zdroj: vlastní zpracování dle Nedělníková (2020)

Od roku 2010 do roku 2019, byl hlášen necelý milion dopravních nehod, při kterých bylo usmrceno téměř 7 tisíc osob (ČSÚ, 2021). Společnost přichází v důsledku dopravních nehod o značné množství finančních prostředků, které vznikají ze ztráty produkce, z výplat vdovských a invalidních důchodů, z rostoucích nákladů spojených s hospitalizací a další.

Povinné hlášení dopravních nehod Policii ČR změnilo svá pravidla v jednotlivých letech. V roce 2000 byla povinnost hlásit hmotnou škodu ve výši 10000 Kč, avšak v roce 2008 byla tato částka stanovena již na výši 50000 Kč a o rok později, tedy v roce 2009 dokonce na 100000 Kč. Vlivem těchto změn bylo dosaženo umělého snížení počtu dopravních nehod. Pokud bychom srovnali léta 2010-2019, tedy v době po zavedených výše zmíněných pravidlech povinného hlášení, tak lze pozorovat rostoucí trend v počtu výskytů dopravních nehod. $V$ roce 2011 bylo hlášeno 75 tisíc dopravních nehod, ale v roce 2019 jich bylo hlášeno již 107 tisíc. Uvedenou statistiku lze podpořit také zahraničními statistikami, které potvrzují rostoucí počet dopravních nehod, a s tím spojených zranění či dokonce úmrtí. Tento trend potvrzují státy jako např́íklad Slovensko (Hudec et al., 2021), Itálie (Bertoli and Grembi, 2021), Korea (Kim et al., 2020), Čína (Yan et al., 2021) a mnoho dalších.

Dopravní nehody tvoří jednu z často vyskytujících se událostí, které mohou přerůst až do MU. Česká republika (dále jen ČR), jakožto tranzitní země, má z tohoto důvodu vyšší pravděpodobnost výskytu dopravních nehod než jiné evropské státy. Proto je důležité věnovat zvýšenou pozornost připravenosti složek integrovaného záchranného systému (dále jen IZS) při dopravních nehodách a snažit se eliminovat další škody a zajistit co možná nejmenší časové prodlevy při společném zásahu. Na základě uvedených statistik a referencí autorů lze usuzovat, že se jedná o téma velmi aktuální, a proto se autoři rozhodli této problematice věnovat. $Z$ tohoto důvodu je cílem článku simulace reálné dopravní nehody a vyhodnocení společného zásahu složek IZS při provádění záchranných a likvidačních pracích. 


\section{METODOLOGIE}

Metodologie vychází z úvahy uvedené v práci (Veselík, 2013), že každá složka, jež vstupuje do procesu řešení nastalé dopravní nehody, musí splnit svůj určený úkol, aby bylo možné tuto situaci zvládnout bez delších průtahů a zabránilo se dalším ohrožením. Jednotlivé složky IZS vyslané na místo dopravní nehody pak plní úkoly stanovené zákonem, podle kterých byly zř́zeny. Na struktuře uvedené na obr. 3 představuje vrcholovou událost likvidace následků dopravní nehody a zabránění dalším škodám. Jednotlivé lépe zvládnutelné celky jsou rozepsány pod vrcholovou událostí a jsou vyjádřeny pomocí podstatných jmen.

Největší podíl vyobrazených celků při dopravní nehodě spadá na bedra Hasičského záchranného sboru České republiky (dále jen HZS ČR), jež zde má 4 zastoupení, kterými jsou „informace“, „lidé vyproštěni“, „místo zajištěno“ a „obnova“. V prŕípadě „informace“ se jedná o přijetí hlášení o nastalé nehodě, její předběžné vyhodnocení, vyslání příslušných složek a zaznamenání údajů do systému. Můžeme konstatovat, že jde o klíčový celek, protože nahlášené informace jsou ihned analyzovány a podle nich dochází k vydání rozhodnutí kolik techniky a osob vyslat. Zároveň se jedná o nejvíce problematickou fázi, protože účastníci nebo svědci dopravní nehody mohou být v šoku a v takovém př́ípadě může dojít ke zkreslení informací o počtu havarovaných dopravních prostředků, počtu ohrožených osob nebo chybné lokalizaci dopravní nehody. Další celek spadající do kompetence HZS ČR je vyproštění osob uvězněných v havarovaných dopravních prostředcích. Dále pak zajištění místa nehody, aby se zabránilo případnému požáru a úniku pohonných hmot do okolí a také obnova místa nehody, kterou se rozumí zejména úklid vozovky.

Celek „lidské životy zachráněny“ spadá do kompetence ZZS, jejímž prvořadým úkolem je okamžité ošetření osob v místě nehody a převoz pacientů do příslušných zdravotnických zařízení. $V$ těchto případech je také možné využít služeb letecké záchranné služby.

Posledními celky jsou „regulace dopravy“ a „dokumentace stop“, které jsou v režii Policie ČR. Ta po př́ijezdu na místo nehody řídí dopravu a pomáhá se shromažd'ováním podkladů. Ty pak dále analyzuje a snaží se zjistit příčinu vzniklé dopravní nehody. Tento proces zahrnuje také výslechy účastníků nehody a dalších možných svědků.

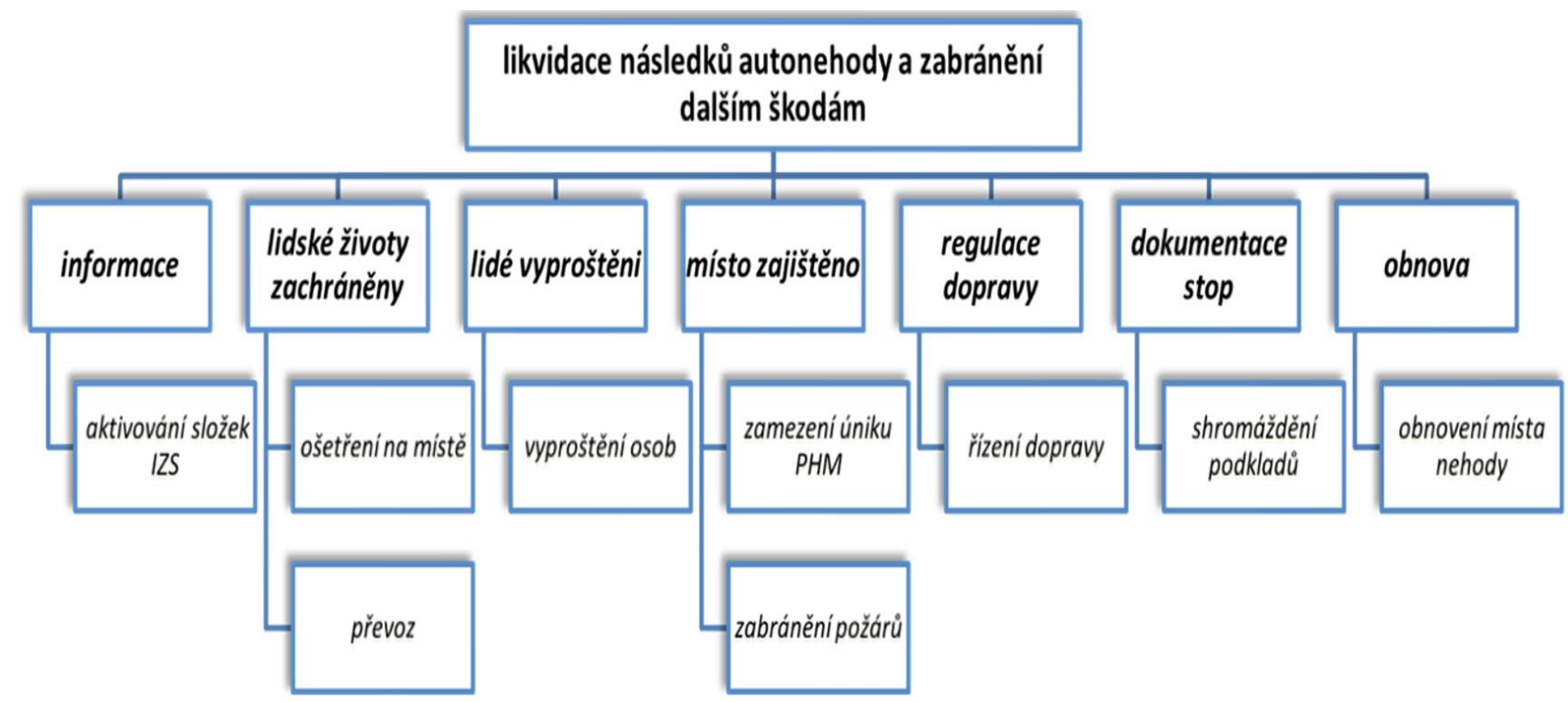

Obr. 3 Plnění úkolů složek IZS při řešení dopravní nehody; zdroj: Veselík (2013)

Pro vyhodnocení společného zásahu složek IZS při dopravní nehodě byl použit program MS Project (Bagchi et al., 2017), konkrétně metoda kritické cesty (Critical path method - CPM). Tato metoda je založena na vyhledávání a analýze kritické cesty při zásahu složek IZS - nejdelšího sledu úkolů, které neobsahují žádné časové rezervy (Svozilová, 2016). Cílem metody je odhalení časových rezerv při 
provádění jednotlivých činností a tím optimalizace, resp. minimalizace doby realizace celého zásahu. Činnosti, u kterých neexistuje žádná časová rezerva, se nazývají kritické činnosti, které přísluší kritickým hranám. Kritické hrany v síti pak určují kritickou cestu mezi vstupním a výstupním uzlem sítě. Metodu kritické cesty lze v praxi využít pro řešení takových situací, kde jsou známy doby trvání činností dle minulých zkušeností nebo údajů o minulých nastalých událostech. Ale také v případech, kde nejsou doby trvání statisticky určeny.

Pro simulaci společného zásahu složek IZS byl použit Ganttův diagram, pomocí kterého lze znázornit sled úkolů. Proto je vhodné ho použít pro simulaci struktury zásahu při řešení vzniklé dopravní nehody. Sloupce uvedené v Ganttově diagramu, ukazují název činnosti (úkolu), dobu trvání příslušné aktivity, čas zahájení, čas dokončení, předchůdce a kdo vykonává. Horizontálně sloupce zobrazují časové období. Podle délky plánovaní je vyobrazeno období v odpovídajících podrobnostech (minuty, hodiny a dny). V řádcích se pak zobrazují dílčí úkoly. Úkoly představují činnosti v takovém pořadí, které odpovídají logickému sledu. Délka trvání aktivit je pak vztažená k časovému období. Díky využití softwarových nástrojů je možno Ganttův diagram doplnit o všechny typy vazeb s překryvy a prodlevami a znázornit kritickou cestu (Svozilová, 2016). Při tvorbě Ganttova diagramu je vyžadováno dodržování následujících pravidel. Mezi první pravidlo patř́í, že diagram má jeden začátek a jeden konec. Dále je nutné dodržet, aby šipky byly orientovány zleva doprava a reprezentovaly tak tok času. Významnou pomůckou pro řazení činností jsou tzv. milníky, které představují významné události v rámci zásahu složek IZS, často indikující konec nebo zahájení další fáze společného zásahu, rozhodnutí o změně postupu řešení, opakování etapy nebo ukončení zásahu (Doležal et al., 2016).

\section{VÝSLEDKY}

V následující části článku je představena simulace společného zásahu složek IZS při reálné dopravní nehodě, která se stala na ulici Sokolovská v Litomyšli. Krajské operační středisko Pardubického kraje IZS přijímá hlášení o vzniklé situaci. Popis mimořádné události zní: Došlo ke střetu osobního vozidla s nákladním automobilem MAN na silnici I/35 křižovatka u Škoda servis v Litomyšli, směr Vysoké Mýto viz. obr. 4 (levý obrázek). Informace, které obdrželo krajské operační a informační středisko (dále jen KOPIS), jsou poměrně přesné. Na základě uvedeného telefonátu známe přesně místo dopravní nehody, protože v tomto okolí se nachází pouze jedna křižovatka. Poměrně často se ale stává, že hovory účastníků a jejich poskytnuté informace jsou velice nepřesné. $Z$ uvedeného telefonátu ale nelze přesně určit počet zraněných. Zejména je důležitá informace, jestli jde o plně obsazený osobní automobil anebo pouze o jednu osobu, tedy řidiče.
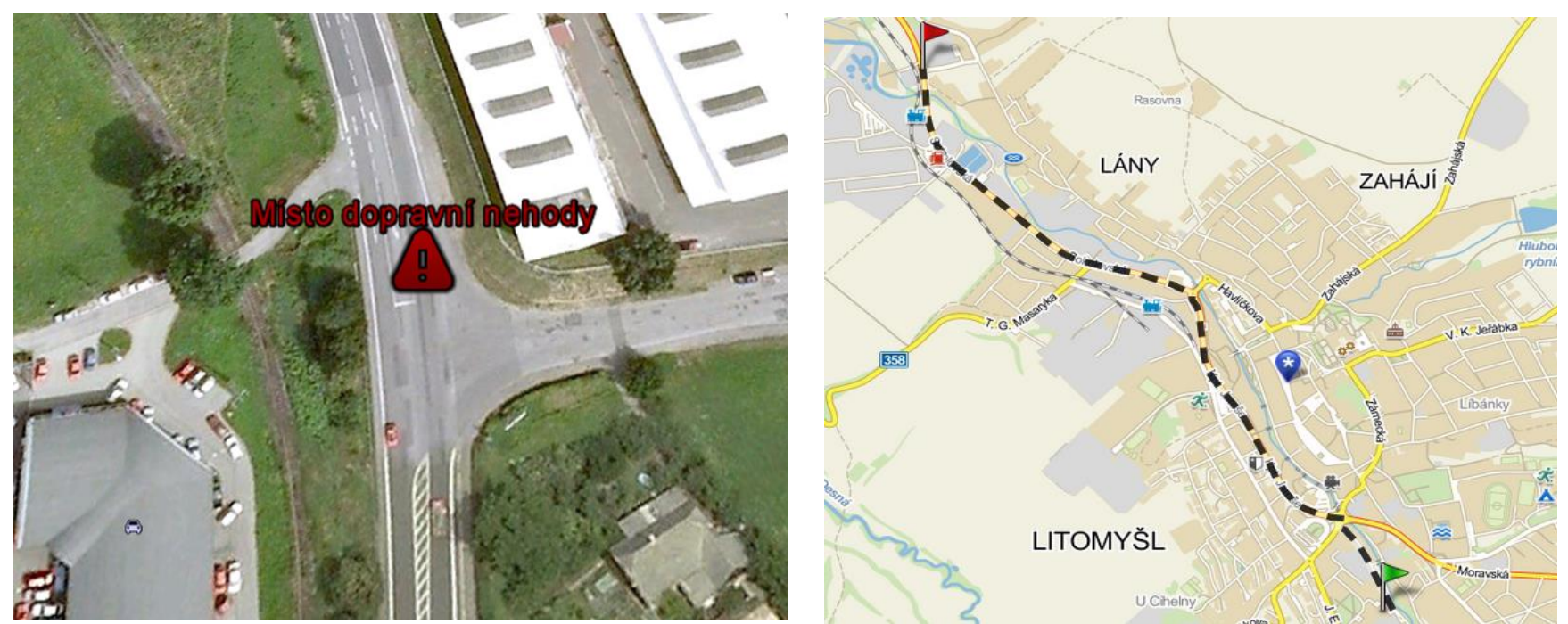

Obr. 4 Místo dopravní nehody (levý obrázek), vzdálenost stanice HZS a ZZS od místa nehody (pravý obrázek); zdroj: Mapy (2021) 
KOPIS předá hlášení věcně př́slušnému operačnímu středisku složky IZS a současně informuje ostatní operační střediska základních složek IZS, které na místo nehody ihned vyšlou zasahující jednotky, konkrétně jednotku HZS, ZZS a obecní policii z Litomyšle, dále pak Policii ČR ze Svitav a Litomyšle.

Zpráva o zásahu poskytnutá HZS Litomyšl uvádí, že na místo dopravní nehody prvně dojela posádka HZS Litomyšl - viz pravý obrázek na obr. 4 (vzdálenost stanice HZS a ZZS Litomyšl od místa dopravní nehody), která v osobním vozidle Seat Cordoba našla dvě osoby. Ihned po HZS na místo přijela ZZS Litomyšl - viz pravý obrázek na obr. 4, kde zelený bod na mapě představuje umístění stanice HZS a ZZS Litomyšl a červený bod pak přesné místo dopravní nehody. Policie ČR mezitím zcela uzavřela silnici I/35 v úseku dopravní nehody a dopravu odklonila po staré vozovce směr Vysoké Mýto. Zasahující jednotka HZS pomocí rozpínáku vyprostila řidiče a spolujezdce. Po zadokumentování nehody dopravní policií, pomohla naložit usmrcené osoby do pohřebního vozu. Pro obě vozidla přijela odtahová služba a zasahující jednotka HZS provedla úklid vozovky od sorbentů a úlomků aut. Nakonec Policie ČR uvolnila silnici I/35 a zasahující jednotky se vrátily zpět na základnu.

Pro vyhodnocení zásahu složek IZS byl použit Ganttův diagram - viz. obr. 5, který představuje graficky naplánované posloupnosti činností v čase. Dále je vyznačena kritická cesta, tedy nejdelší možná cesta z počátečního bodu do koncového bodu grafu - viz. obr. 5 (červeně vyznačené úkoly). Tato cesta prŕmo ovlivňuje délku trvání záchranných a likvidačních prací. Ve výchozím nastavení zobrazuje MS Project pouze jednu kritickou cestu, tedy jedinou celkovou kritickou cestu, která ovlivňuje vyřešení posledního úkolu a tím i celou dopravní nehodu. V sít’ovém diagramu lze ale pro každou nezávislou posloupnost úkolů zobrazit více kritických cest. To je užitečné v případě rozdělení záchranných a likvidačních prací do více fází, kde chceme zobrazit kritickou cestu pro různé fáze.

Úkoly uvedené na kritické cestě nemají vyšší nebo nižší důležitost než ostatní úkoly. Změna úkolů na kritické cestě ovšem vede ke změně kritické cesty. Proto je důležité zaměřit se na úkoly uvedené na kritické cestě, pokud chceme zabezpečit dokončení nastalé dopravní nehody v co nejkratším časovém horizontu. Z výše uvedeného je zřejmé, že zpoždění úkolů na kritické cestě se určitě promítne do zpomalení řešení dané dopravní nehody, naopak zrychlení úkolů na kritické cestě zkracuje její trvání.

Pro simulaci záchranných a likvidačních prací byly data získána od pracovníků HZS v Litomyšli a na základě konzultací s pracovníky Policie ČR v Litomyšli. Dojezdové časy HZS a ZZS byly v limitu, který jim stanovují platné právní předpisy. Počet zraněných účastníků dopravní nehody byl celkem tři, přičemž řidič i spolujezdkyně na následky zranění zemřeli. Řidič nákladního vozidla vyvázl s lehkými zraněnými. Hmotné škody na vozidlech byly odhadnuty na 130 tisíc korun. Příčinou dopravní nehody bylo nedání přednosti v jízdě, přičemž řidič osobního vozidla vyjížděl na hlavní silnici I/35 z vedlejší komunikace a došlo ke střetu.

Použitý program MS Project se jeví jako vhodný nástroj pro simulaci a vyhodnocení podobných zásahů, protože umožňuje výpočet kritické cesty. Kritická cesta v rámci dané dopravní nehody je následující: telefon KOPIS - aktivace Policie ČR - výjezd zasahujících jednotek Policie ČR - př́ijezd Policie ČR na místo nehody - Policie ČR řídí dopravu - Policie ČR uzavírá silnici I/35 a odklání dopravu - povolání odtahové služby - př́jezd odtahové služby - naložení a odtažení vozů - HZS úklid vozovky - odjezd HZS - návrat HZS na stanici. Pokud bychom chtěli zkrátit dobu řešení vzniklé dopravní nehody, je nutné zaměřit se na úkoly uvedené na kritické cestě, která nám ukazuje délku trvání celého zásahu. 


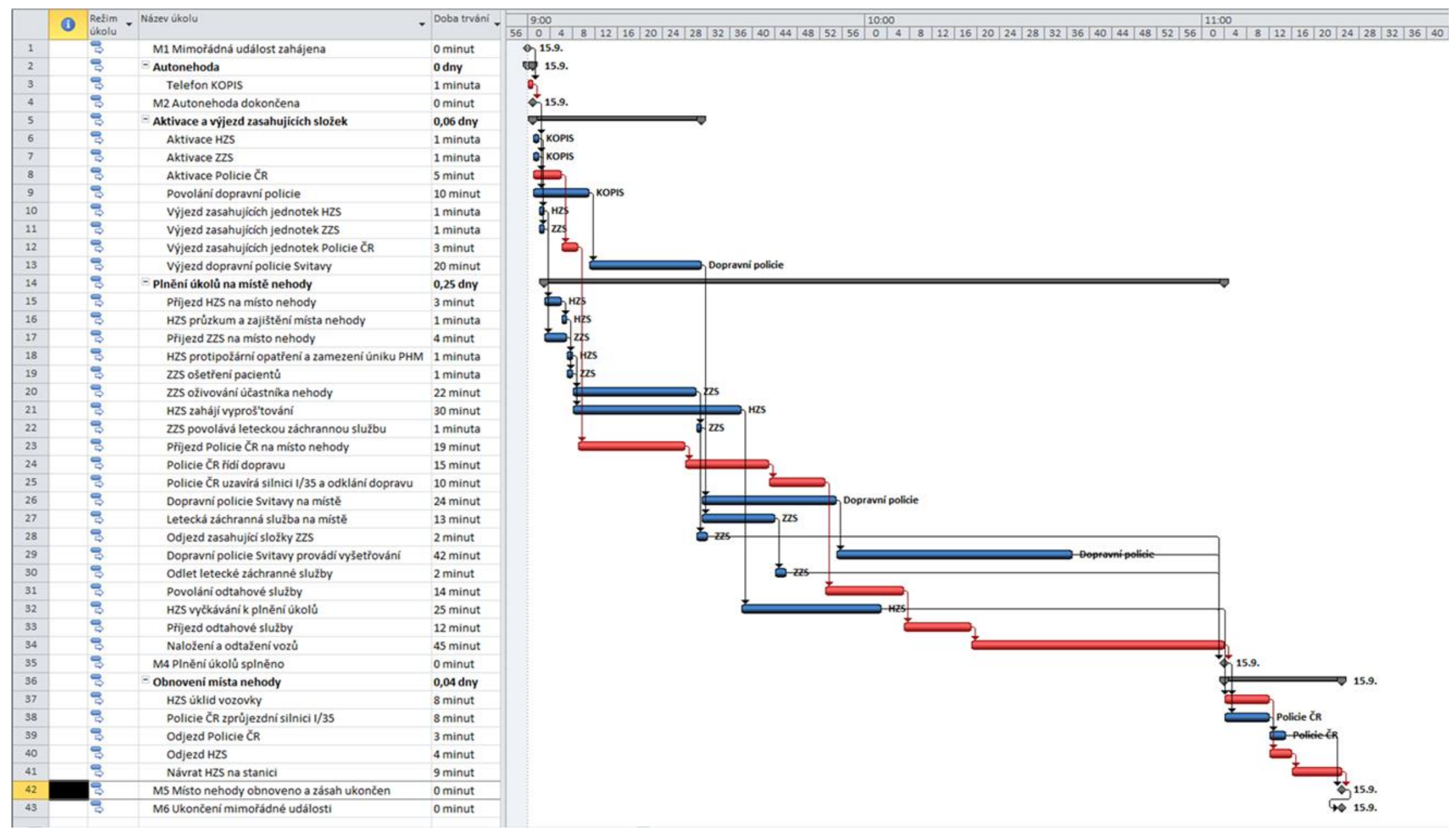

Obr. 5 Struktura zásahu složek IZS znázorněna pomocí Ganttova diagramu s vyznačením kritické cesty 


\section{ZÁVĚR}

Dopravní nehody představují jednu z nejčastějších mimořádných událostí, kterou řeší složky IZS (Nedělníková, 2020). Na základě statistik (Nedělníková, 2020), (ČSÚ, 2021) a referencí autorů (Hudec et al., 2021), (Bertoli and Grembi, 2021), (Kim et al., 2020), (Yan et al., 2021), (Rehak et al., 2020) lze usuzovat, že se jedná o téma velmi aktuální. Z tohoto důvodu byla hlavní pozornost zaměřena na simulaci společného zásahu složek IZS při řešení reálné dopravní nehody menšího rozsahu bez úniku nebezpečné látky.

Řešení dopravních nehod představuje složitý proces, který obsahuje velké množství faktorů, a tudíž nelze zobecnit (Goncharov et al., 2021). Existují ovšem některé činnosti, které se provádí vždy, tzv. „styčná místa“. Nicméně konkrétní činnosti závisí na dané dopravní nehodě. Hlavní př́ínos článku spočívá v ukázce projektového řízení v praxi a v představení možností, které v tomto směru nabízí program MS Project. Vše je demonstrováno na reálné dopravní nehodě, která se stala na silnici I/35 v Litomyšli na výjezdu z města směrem na Vysoké Mýto. Stěžejní částí článku je komplexní struktura celého zásahu složek IZS, která je vyobrazena v Ganttově diagramu, zachycujícího jednotlivé vazby mezi činnostmi. Celému řešení dopravní nehody je přiřazena časová osa, která přehledně zobrazuje délku trvání jednotlivých činností. Po skončení zásahu je možné vyhodnotit kritické úkoly, které ovlivňují celkové dokončení záchranných a likvidačních prací.

Využití výstupů článku lze očekávat zejména ve výchovně vzdělávacím procesu studentů se zaměřením na krizový management a ochranu obyvatelstva. Dále pak při cvičeních složek IZS při dopravní nehodě menšího rozsahu. $\mathrm{V}$ dalším výzkumu by měla být pozornost věnována zejména spolupráci s dalšími experty pro jednotlivé sektory, která by mohla přinést zkvalitnění analyzovaných zásahů, spočívajících ve vytvoření informačního systému, který by zpracovával data z místa dopravní nehody a na základě těchto údajů by následně vyhodnocoval situaci a navrhoval následný postup při společném zásahu.

\section{Literatura}

Bagchi, T.P., Sahu, K. and Jena, B.K. 2017. Why CPM is not good enough for scheduling projects. IEEE International Conference on Industrial Engineering and Engineering Management (IEEM). Singapure, 10. - 13. 12. 2017, 1748-1752.

Batima, P., Natsagdorj, L. and Batnasan, N. 2013. Vulnerability of Mongolia's pastoralists to climate extremes and changes. Climate Change and Vulberability, 67-87.

Bernatik, A., Senovsky, P., Senovsky, M. and Rehak, D. 2013. Territorial Risk Analysis and Mapping. Chemical Engineering Transactions, 31, 79-84. <https://doi.org/10.3303/CET1331014>

Bertoli, P. and Grembi, V. 2021. The Political Cycle of Road Traffic Accidents. Journal of Health Economics, 76, 1-18. <https://doi.org/10.1016/j.jhealeco.2021.102435>

ČSÚ. (C) 2021. Nehody v silniční dopravě. [Online]. Dostupné z:

https://www.czso.cz/csu/czso/nehody_v_doprave_casove_rady [cit.: 2021, 26. duben].

Doležal, J., Lacko, B., Hájek, M., Cingl, O., Krátký, J. a Bočková, K.H. 2016. Projektový management. Komplexně, prakticky a podle světových standardů. Praha: Grada Publishing.

Goncharov, S.F., Barov, A.V. and Mordovsky, E.A. 2021. O účelnosti organizace monitorování zdravotních a hygienických následků dopravních nehod. Biomedicínské a sociálně psychologické problémy bezpečnosti v krizových situacích, 1, 31-39. <https://doi.org/10.25016/2541-7487-2021-0-1-31-39> 
Hudec, J., Sarkan, B., Caban, J. and Stopka, O. 2021. The Impact of Driving Schools' Training on Fatal Traffic Accidents in the Slovak Republic. Scientific Journal of Silesian University of Technology. Series Transport, 110, 45-57. <https://doi.org/10.20858/sjsutst.2021.110.4>

Kampova, K., Lovecek, T. and Rehak, D. 2020. Quantitative Approach to Physical Protection Systems Assessment of Critical Infrastructure Elements: Use Case in the Slovak Republic. International Journal of Critical Infrastructure Protection, 30, 1-11. <https://doi.org/10.1016/j.ijcip.2020.100376>

Kim, D.-Y., Hong, S.-H., Han, S.Y., Kim, W.-Y., Oh, S.-H., Lee, H.-W. and Woo, H.-S. 2020. The Research Trends of Pharmacopuncture Therapy on Cervical Pain Caused by Traffic Accidents. Journal of Pharmacopuncture, 23(4). 201-211. < https://doi.org/10.3831/KPI.2020.23.4.201>

Luskova, M. and Leitner, B. 2018. Extreme Weather Impact on Transportation and Energy Infrastructure. Proceedings of 22 nd international scientific conference. Transport Means 2018. Trakai, Lithuania, 3. - 5. 10. 2018. Litva: Kaunas University of Technology, 569-573.

Mapy. (C) 2021. Mapový portál. [Online]. Dostupné z:

<https://mapy.cz/zakladni?x=14.5045000\&y=50.0804000\&z=11> [cit.: 2021, 26. duben]

Munasinghe, N.L. and Matsui, K. 2019. Examining disaster preparedness at Matara District General Hospital in Sri Lanka. International Journal of Disaster Risk Reduction, 40, 1-10. <https://doi.org/10.1016/j.ijdrr.2019.101154>

Nedělníková, H. 2020. Statistická ročenka 2019. Časopis 112, 3, př́loha.

Rehak, D. Patrman, D., Brabcova, V. and Dvorak, Z. 2020. Identifying Critical Elements of Road Infrastructure using Cascading Impact Assessment. Transport, 35(3), 300-314. <https://doi.org/10.3846/transport.2020.12414>

Rehak, D., Senovsky, P., Hromada, M., Lovecek, T. and Novotny, P. 2018. Cascading Impact Assessment in Critical Infrastructure System. International Journal of Critical Infrastructure Protection, 22, 125-138. <https://doi.org/10.1016/j.ijcip.2018.06.004>

Svozilová, A. 2016. Projektový management. Systémový přístup k řízení projektů. Praha: Grada Publishing.

Veselík, P. 2013. Scénáře záchranných a likvidačních prací v operacích IZS. Brno. Diplomová práce. 87s. Univerzita obrany. Vedoucí práce prof. Ing. Jiří Urbánek, CSc.

Yan, M., Chen, W., Wang, J., Zhang, M. and Zhao, L. 2021. Characteristics and Causes of Particularly Major Road Traffic Accidents Involving Commercial Vehicles in China. International Journal of Environmental Research and Public Health, 18(8), 1-18. <https://doi.org/10.3390/ijerph18083878> 